\title{
Hyvän elämän edellytyksiä etsimässä - SoWell-tutkimushanke keskittyy sosiaaliseen hyvinvointiin ja sen parantamiseen
}

Suomen väestöstä nyt jo viidesosa ja vuosikymmenen kuluttua lähes neljäsosa on yli 65-vuotiaita (THL 2018). Väestön vanheneminen on globaali ilmiö, mutta niin Suomessa kuin muuallakin keskustelu on pääasiassa kohdistunut eläkekuluihin sekä hoiva- ja terveyspalveluiden tarpeeseen ja niiden kustannuksiin. Vähemmän on keskusteltu väestön vanhenemisen vaikutuksista koko yhteiskuntaan, ikääntyvän väestön heterogeenisuudesta ja vanhojen ihmisten erilaisuudesta tarpeidensa, resurssiensa ja kykyjensä suhteen. Yhtä tärkeää kuin puhe terveyspalveluista ja eläkkeistä on puhe ikääntyvien sosiaalisesta hyvinvoinnista ja elämänlaadusta. Keskeinen kysymys on se, miten luodaan yhteiskunta, joka tukee kaikenikäisten kansalaisten hyvinvointia ja osallisuutta. Yhteiskuntatason ohella sosiaalinen hyvinvointi ja hyvä elämänlaatu kytkeytyvät myös paikallisiin olosuhteisiin ja niiden tarjoamiin (tai estämiin) toimintamahdollisuuksiin (Brooker, Scully \& Clancy 2011, Buffel ym.
2014, Marventano ym. 2015, Missotten ym. 2009.)

Sosiaalista hyvinvointia on määritelty varsin eri tavoin. Keskeisinä ulottuvuuksina on pidetty sosiaalisen yhteenkuuluvuuden tunnetta, yksinäisyyden poissaoloa, onnellisuutta ja turvallisuuden tunnetta. Tärkeiksi on havaittu myös mahdollisuus itselle mielekkääseen toimintaan ja itsensä toteuttamiseen sekä osallistumiseen oman yhteisön toimintaan järjestöjen, harrastusryhmien tms. kautta (Charles \& Mavandi 2003.) SoWell-tutkimushankkeessa keskeinen idea on ikäihmisten osallisuuden vahvistaminen, mikä tarkoittaa sitä että kiinnostuksen kohteena ovat ihmisten omat näkemykset hyvinvoinnistaan ja siihen vaikuttavista tekijöistä.Toisin sanoen pyrimme antamaan ikäihmisille itselleen valtaa määritellä mitä sosiaalinen hyvinvointi merkitsee ja miten siihen voisi vaikuttaa.

Hankkeen keskeisenä tavoitteena on tuottaa tietoa ja välineitä ikääntyvien ihmisten sosiaalisen hyvinvoinnin parantamiseksi 1) kartoittamalla ikääntyvien ihmisten omia käsityksiä sosiaalisen hyvinvoinnin ulottuvuuksista ja parantamisen keinoista, 2) toimimalla yhteistyössä muiden hankkeiden ja järjestöjen kanssa sosiaalista hyvinvointia lisäävien toimien toteuttamiseksi ikäihmisten omien näkemysten mukaisesti, 3) seuraamalla hyvinvoinnin parantamiseen tähtäävien hankkeiden merkitystä ikääntyvien ihmisten elämälle ja itse arvioidulle sosiaaliselle hyvinvoinnille ja 4) herättämällä keskustelua ja kehittämällä käytäntöjä ja malleja sosiaalisen hyvinvoinnin parantamiseksi.

Yksi tutkimusteema, kolme erilaista aineistoa

SoWell-tutkimuksessa ikäihmisten hyvinvointia kartoitetaan kolmella erillisellä, mutta yhteen kietoutuvalla aineistolla. Syksyn 2018 aikana Jari Pirhonen ja Katariina Tuominen järjestivät yhteensä seitsemän ryhmäkeskustelua ikäihmisten kanssa Tampereella ja sen lähiympäristössä. Ryhmäkeskusteluaineistoa keräämällä halusimme kartoittaa jaettuja näkemyksiä hyvin- 
voinnista. Ryhmäkeskusteluissa osallistujia pyydettiinkin kertomaan, mitä hyvinvointi heidän mielestään ylipäätään on, millaiset asiat siihen vaikuttavat ja muuttuuko hyvinvoinnin kokemus tai merkitys ikääntymisen myötä. Keskusteluteemoja olivat lisäksi asuinympäristön, palvelujen, järjestötoiminnan ja teknologian vaikutukset hyvinvointiin. Muita aiheita nostettiin keskusteluun tilanteen ja keskustelijoiden aloitteiden mukaan, jolloin tilaa jäi ihmisten omille merkityksenannoille ja uusille ja yllättävillekin hyvinvointiin liittyville näkökannoille. Keskusteluihin rekrytoitiin eläkeikäisiä ihmisiä Tampereen Lähitorien, palvelukeskusten, vanhusneuvoston ja Miessakit ry:n kautta. Ryhmien kokoamisessa tavoitteena oli saada mukaan erilaisia ja erilaisessa asemassa olevia ikäihmisiä. Ryhmien osallistujiksi saatiinkin erilaisiin yhdistyksiin ja harrastusryhmiin osallistuvia, erilaisissa asumismuodoissa asuvia sekä kaupunkialueilla ja maaseutumaisesti asuvia miehiä ja naisia. Myös eri ikäluokat olivat edustettuina, sillä osallistujien iät vaihtelivat välillä 55 ja 101 .

Ryhmäkeskustelut on nauhoitettu ja litteroitu sanatarkaksi tekstiksi. Tätä tutkimusesittelyä kirjoitettaessa ryhmäkeskusteluaineiston analyysit ovat alkamassa. Ryhmäkeskusteluaineiston analyysillä paitsi vastataan osaltaan hyvinvoin- tiin liittyviin tutkimuskysymyksiin, pohjustetaan yksilöhaastatteluja, joissa ryhmäkeskusteluissa tärkeiksi nousseita teemoja syvennetään. Yksilöhaastattelut aloitettiin loppuvuodesta 2018 ja niitä jatketaan tammi-helmikuussa 2019. Yksilöhaastatteluja on suunniteltu tehtävän neljäkymmentä, mutta aineistonkeruussa edetään joustavasti sen mukaan, miten aineisto saturoituu. Osallistujista osa on ryhmäkeskusteluihin osallistuneita ja osa uusia henkilöitä. Haastateltavien rekrytoimista ohjaa ajatus, että on tärkeää saada mukaan myös sellaisia henkilöitä, jotka eivät ole aktiivisesti mukana jossain harrastus- tai yhdistystoiminnassa, ja jotka viettävät suurimman osan ajastaan kotioloissa. Erityisen tärkeää on saada mukaan sellaisia henkilöitä joiden voi katsoa olevan haavoittuvassa asemassa esimerkiksi taloudellisista tai terveyssyistä. Tämän tavoitteen toteutumiseksi osallistujia etsitään yhteistyössä Tampereen kaupungin ja järjestöjen kanssa. Tässäkin aineistonkeruussa tavoitteena on saada mukaan erilaisissa elämäntilanteissa olevia perheellisiä ja yksin asuvia henkilöitä. Yksilöhaastattelujen tavoitteena on syventää ryhmäkeskustelujen antamaa kuvaa hyvinvoinnista ja niissä pystytään myös ryhmäkeskusteluja paremmin lähestymään mahdollisesti arkaluonteisia aiheita kuten lä- heisten menetyksiä, terveyden heikkenemistä ja hoivajärjestelyjä, ja niiden merkitystä hyvinvoinnille.

Tutkimuksen kolmannessa vaiheessa tullaan rakentamaan ryhmäkeskustelujen ja haastattelujen tulosten pohjalta kyselylomake. Kyselyn tavoitteena on selvittää, missä määrin tutkimuksen aikaisemmissa vaiheissa esiin tulleet sosiaalisen hyvinvoinnin elementit ja niiden parantamiseksi esitetyt toimet ovat yleistettävissä. Laadullinen aineistonkeruu tehdään Pirkanmaalla ja kyselyn tavoitteena on laajentaa tarkastelua koko maahan ja saada tietoa esimerkiksi alueellisista ja sosiaalisen taustan mukaisista eroista hyvinvoinnissa. Suunnitelmissa on lisäksi tutkimuksen viimeisessä vaiheessa seurantahaastattelujen avulla tarkastella alkuvaiheen yksilöhaastatteluihin osallistuneiden henkilöiden tilanteita.

Tutkimme kehittääksemme, kehitystä tutkien

SoWell-tutkimushankkeen tarkoituksena on antaa ääni ikääntyville ihmisille itselleen. Ikääntyneen väestön määrän kasvaessa hanke tuottaa uutta tutkimustietoa alueelta, jonka yhteiskunnallinen merkitys kasvaa vuosi vuodelta. Hankkeen keskeinen tavoite on edistää ikäihmisten hyvinvointia ja kehittää ikäihmisten näkemyksille perustuvia käy- 
täntöjä ja malleja, joita kunnat, järjestöt ja muut toimijat voivat soveltaa toiminnassaan. Käytännöllisten tavoitteiden lisäksi hanke tuottaa uutta tutkimustietoa julkaisujen ja opinnäytteiden muodossa. Tutkimuksessa kehitetään lisäksi uudenlaista osallistavan tutkimuksen yhteistyötä ikäihmisten ja tutkijoiden kesken, joten metodologinen kehitystyö on myös osa tutkimusta. Suunniteltu viiden vuoden kesto ja seurantahaastattelut mahdollistavat sekä tutkimustulosten käytäntöön viemiseen että uusien käytäntöjen toimivuuden tutkimisen.

Tiedonintressimme on emansipatorinen eli tutkimuksen kohderyhmää voimaannuttamaan pyrkivä. Tutkimushankkeen alusta lähtien olemme saaneet esimerkiksi ryhmäkeskusteluihin osallistujilta palautetta siitä, että ikäihmiset arvostavat heihin kohdistuvaa kiinnostusta. Ryhmäkeskusteluissa onnistuttiin tavoittamaan luottamuksellinen ja turvallinen ilmapiiri mistä kertoo esimerkiksi se, että niissä kerrottiin hyvinkin suoraan myös ikävistä kokemuksista. Hankkeen yhtenä tavoitteena on mahdollisuuksien mukaan vaikuttaa myös välittömästi osallistujien arkeen ja hyvinvoinnin kokemukseen. Ikävien kokemusten kertominen ja kokemuksille saatu ymmärrys ja hyväksyntä ryhmässä vaikut- tivat ensimmäisten havaintojemme mukaan olevan tärkeitä osallistujille. Aineiston analyysissä yksi tärkeä tarkastelunäkökulma on se miten ryhmäkeskusteluihin osallistuminen voi edistää hyvinvointia samoin kuin itseymmärrystä omista voimavaroista. Tärkeä näkökulma on myös kokemusten ja tietojen vaihto, johon myös tutkijat osallistuvat. Esimerkiksi eräässä ryhmässä oli mies, joka koki olevansa asuntonsa vanki, sillä hänen asuintalonsa ulko-ovia oli yksin pyörätuolilla liikkuvan mahdoton avata, eikä sukulaisilla ollut mahdollisuutta käydä kuin kerran viikossa. Ryhmäkeskustelun vetäjät Jari Pirhonen ja Katariina Tuominen kertoivat miehelle vapaaehtoistyön mahdollisuuksista auttaa, ja hän kiinnostuikin asiasta. Keskustelun jälkeen tutkijat vinkkasivat asiasta myös miehen tuntemalle Lähitorin sosiaalityöntekijälle, joka järjesti miehelle ulkoiluapua. Sosiaalisen hyvinvoinnin lisääminen on paitsi yksi keskeinen tutkimuksen päämäärä, myös väline päämäärään pääsemiseksi.

\section{Kohti konkreettisia toimia}

Koska vastaavanlaista iäkkäiden ihmisten omiin näkemyksiin perustuvaa useamman vuoden kestävää eri toimijoiden yhteistyöhanketta ei aiemmin ole Suomessa toteutettu, pyrimme siihen, että hanke nousee tärkeäksi esimerkiksi sekä toteuttamistapansa että tulostensa takia. Tutkimuksemme tavoitteena on avata osallisuuden mahdollisuuksia ikäihmisille sekä kehittää osallistavan tutkimuksen välineitä. Yliopiston kolmas tehtävä eli yhteiskunnallinen vaikuttavuus on siten hankkeen keskeinen päämäärä. Tavoitteena on myös, että viisivuotisen hankkeen päättyessä tutkimusryhmällä on sanottavaa tutkimustulosten sovellettavuudesta alueellisesti ja yhteiskuntapolitiikassa. Edessämme on pitkä matka. Luotamme siihen, että tulevat vuodet täyttyvät oivalluksen ilosta ja ymmärryksen syvenemisestä tutkimustyön edistyessä. Oman mielenkiintonsa tuovat varmasti tulevat kohtaamiset hyvin erilaisten ikäihmisten kanssa. Erityistä tässä hankkeessa on se, että tutkijoilla on myös lupa osallistua hyvinvoinnin edistämiseen ja toimia konkreettisesti tilaisuuden tullessa. Tutkimuksen tuloksista tullaan tiedottamaan laajasti alueellisissa seminaareissa, mediassa ja tutkimusjulkaisuissa.

\section{Jari Pirhonen, Outi Jolanki, Katariina Tuominen ja Marja Jylhä, \\ Yhteiskuntatieteiden tiedekunta, Tampereen yliopisto \\ Yhteydenotto: jari.pirhonen[at]tuni.fi}




\section{Kirjallisuus}

Brooker, D., Argyle, E., Scully, A.J. \& Clancy, D. (2011). The enriched opportunities programme for people with dementia: a cluster-randomised controlled trial in ten extra care housing schemes. Aging and Mental Health, 15, 10081017.

Buffel T., De Donder L., Phillipson C., Dury S., De Witte N. \& Verte D. (2014). Social participation among older adults living in medium-sized cities in Belgium: The role of neighbourhood perceptions. Health Promotion International, 29(4), 655-668.

Charles, S. T. \& Mavandi, S. (2003). Relationships and health across the lifespan. Teoksessa Growing together: Personal relationships across the lifespan, F. Lang \& K. Fingerman (eds.), 240-267. New York: Cambridge University Press.

Marventano, S., Prieto-Flores, M.-E., Sanz-Barbero, B., Martín-García, S., FernandezMayoralas, G., Rojo-Perez, F., Martinez-Martin, P. \& João Forjaz, M. (2015). Quality of life in older people with dementia: A multilevel study of individual attributes and residential care center characteristics. Geriatr Gerontol Int, 15: 104-110.
Missotten, P., Thomas, P., Squelard, G., Di Notte, D., Fontaine, O., Paquay, L., De Lepeleire, J., Buntinx, F. \& Ylieff, M. (2009). Impact of place of residence on relationship between quality of life and cognitive decline in dementia. Alzheimer Disease E Associated Disorders, 23, 395-400.

THL. (2018). Sosiaali- ja terveysalan tilastollinen vuosikirja 2017. Saatavana http://www. julkari.fi/bitstream/handle/10024/135959/URN_ ISBN_978-952-302-970-5. pdf? sequence $=1 \&$ isAllowe$\mathrm{d}=\mathrm{y}$ (käytetty 15.10.2018) 